Proc. Estonian Acad. Sci. Geol., 2005, 54, 2, 112-118

\title{
Thermal behaviour of bone apatite of Recent pike (Esox lucius L.)
}

\author{
Jüri Nemliher and Toivo Kallaste \\ Institute of Geology at Tallinn University of Technology, Estonia pst. 7, 10143 Tallinn, Estonia;
} nemliher@gi.ee

Received 29 December 2004, in revised form 27 January 2005

\begin{abstract}
Thermal properties of bioapatite of Recent pike (Esox lucius L.) vertebrae were studied by means of the whole-pattern-fitting XRD technique. The sample was gradually heated up to $900^{\circ} \mathrm{C}$. Weight loss of the sample heated up to $900^{\circ} \mathrm{C}$ was about $3.05 \mathrm{wt} \%$. The apatite heated up to $900^{\circ} \mathrm{C}$ had lattice parameters $a=9.419 \AA$ and $c=6.881 \AA$. Recrystallization of crystallites took place during heating, being the strongest at temperatures higher than $600{ }^{\circ} \mathrm{C}$. At the temperature of $900^{\circ} \mathrm{C}$ crystallites achieved the dimensions over $1000 \times 1000 \AA$.
\end{abstract}

Key words: bioapatite, XRD whole-pattern-fitting, thermal behaviour, fossilization.

\section{INTRODUCTION}

Mineralized tissues, such as shells, scales, bones, and teeth, constitute the source material for fossilization. From the point of view of materials science, hard tissues of biological systems are a composite of organic and inorganic phases (Peters et al. 2000). In vivo, mineral phase secretion is controlled by organic matrix composition and configuration, and the fully mineralized tissues stay in interaction with organic matrix during organism's life-time. From the mineralogical point of view, bioapatites are a complicated and flexible mineral group, having a wide range of substituting elements and ions on the one hand and several substitution positions for carbonate ions on the other hand (e.g. McConnell 1973; Elliott 1994; Ivanova et al. 2001). Previous studies (Nemliher et al. 1997; Puura \& Nemliher 2001) have shown that in spite of the diversity of exact chemical composition and ionic positioning, the regularity of bioapatite lattice, expressed by lattice parameters, is taxa-specific. Those specific lattice features reflect in vivo conditions because of the protecting influence of organic matrix (Person et al. 1996) after the formation of hard tissue. 
Post mortem conditions differ drastically from those in vivo and result commonly in the destruction of skeleton parts. The rate of this process is determined by the primary organic matter content of the mineralized tissue: the most rapid changes take place in tissues with a high organic matter content (e.g., among Recent organisms, lingulate brachiopod shells; Nemliher \& Kallaste 2002). Golubev (1981) has shown that from the point of view of biomineralization, fossil itself is a mineral aggregate without the protecting influence of organic matter.

Thus, as a precondition for the preservation of a skeletal fragment, certain changes in the biomineral-organic matrix interaction should be assumed, causing alteration of the mineralogical properties of bioapatite. The attempts to track the stages of bioapatite alteration by the XRD technique have shown that the most drastic changes take place immediately after the death of a living organism (Nemliher \& Kallaste 2002). Further alteration proceeds in equilibrium with diagenetic conditions (Nemliher et al. 2004a) and results in the same moderately crystalline carbonated F-apatite (Nemliher \& Puura 1996; Nemliher et al. 1996) as that of sedimentary apatite (McArthur 1985).

Heating has been reported as a convenient tool for modelling post mortem changes and fossilization of skeletal fragments (Golubev 1981; Person et al. 1996). Detailed crystallographic data on thermal behaviour of Recent bioapatite (human bone) are available in Rogers \& Daniels (2002). Our study presents the thermal behaviour of the bioapatite of Recent pike (Esox lucius L.) vertebrae in order to assess the changes in lattice parameter values, structural order, and crystallite dimensions during heating.

\section{MATERIAL AND METHODS}

Recent pike was obtained commercially. After mechanical removal of soft tissues, skeletal fragments were treated with $\sim 20 \% \mathrm{H}_{2} \mathrm{O}_{2}$, buffered by $\mathrm{NH}_{4} \mathrm{OH}$ to remove organic matter, and vertebrae were collected. Bone mineral matter was powdered in an agate mortar.

Apatite was heated gradually up to $900^{\circ} \mathrm{C}$, with a step of $100^{\circ} \mathrm{C}$. After each heating event, about $50 \mathrm{mg}$ of residue was removed, mixed with internal standard ( $\sim 5 \mathrm{wt} \%$ quartz) and analysed by means of XRD, using the HZG-4 diffractometer with Fe-filtered Co-radiation $\left(\lambda_{\mathrm{K} \alpha 1}=1.788965 \AA\right)$. The ranges $28-44$ and $53-65^{\circ}$ of $2 \Theta$ were scanned in a step-scan mode, with a step of $0.02^{\circ}$. Counting times for each step were 6 and $15 \mathrm{~s}$ for the above-referred angular ranges, respectively. The method of X-ray pattern treatment is described in our earlier work (Nemliher \& Kallaste 2002). The only difference from this published method is that the strain values were frozen for $\Delta a=0.020$ and $\Delta c=0.015$, thus, all crystallinity changes were attributed to crystallite dimensions.

To avoid moisture effects, the weight loss of residue was determined separately. About $1 \mathrm{~g}$ of organic-matter-free mineral residue was heated in the same way up to $900^{\circ} \mathrm{C}$. After each step of $100^{\circ} \mathrm{C}$ the residue was removed from the furnace, weighed, and heated on. 


\section{RESULTS AND DISCUSSION}

Data on weight loss are presented in Table 1 and Fig. 1. The weight of the sample heated to $200^{\circ} \mathrm{C}$ was taken as $100 \%$. The weight loss in the interval of $0^{\circ} \mathrm{C} \rightarrow 200^{\circ} \mathrm{C}$ can be attributed to moisture effects and to burning of residual organic matter. The thermal weight loss of bioapatite has been explained by $\mathrm{CO}_{3}$ emanation from the apatite lattice, preferably from the B-site (Elliott 1994; Ivanova et al. 2001). The function found here displays a clear exponential character, which is slightly different from those reported earlier for vertebrate bioapatite (see, e.g., Peters et al. 2000). We attribute this phenomenon to the presence of

Table 1. Weight loss (the sample heated up to $200^{\circ} \mathrm{C}$ was taken as $100 \%$ ), crystallite dimensions in the directions of hk0 $\left(\mathrm{D}_{(\mathrm{hk} 0)}\right)$ and $001\left(\mathrm{D}_{(001)}\right)$, and values of lattice parameters $a$ and $c$, measured on heated bioapatite

\begin{tabular}{l|r|r|c|c|c}
\hline $\begin{array}{c}\text { Temperature, } \\
{ }^{\circ} \mathrm{C}\end{array}$ & $\begin{array}{c}\text { Weight, } \\
\mathrm{wt} \%\end{array}$ & $\begin{array}{c}\mathrm{D}_{(\mathrm{hk0})}, \\
\AA\end{array}$ & $\begin{array}{c}\mathrm{D}_{(001)}, \\
\AA\end{array}$ & $\begin{array}{c}a, \\
\AA\end{array}$ & $\begin{array}{c}c, \\
\AA\end{array}$ \\
\hline 110 & 104.98 & 59 & 160 & 9.446 & 6.869 \\
200 & 100.00 & 56 & 175 & 9.432 & 6.868 \\
300 & 98.92 & 55 & 154 & 9.414 & 6.872 \\
400 & 98.21 & 51 & 147 & 9.412 & 6.877 \\
500 & 97.67 & 71 & 176 & 9.414 & 6.877 \\
600 & 97.31 & 124 & 253 & 9.421 & 6.879 \\
700 & 97.13 & 226 & 360 & 9.421 & 6.880 \\
800 & 97.04 & 452 & 800 & 9.419 & 6.880 \\
900 & 96.95 & 1398 & 1434 & 9.419 & 6.881
\end{tabular}

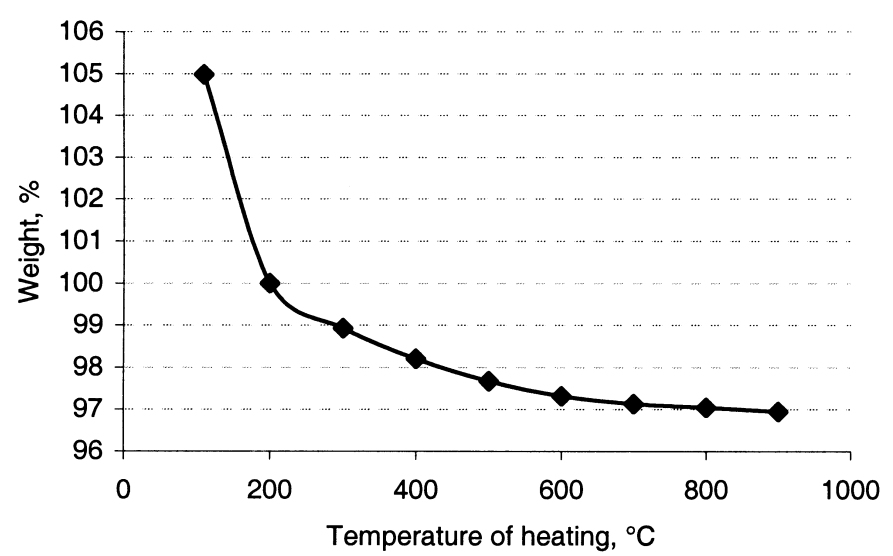

Fig. 1. Weight loss of apatite of Recent pike vertebrae during heating. 
residual organic matter in a bioapatite sample. Most likely we succeeded to remove almost all of the organic part of the bone. This assumption is confirmed by the fact that the exothermal effect occurred at the temperature of $350^{\circ} \mathrm{C}$ (fig. 1 in Peters et al. 2000) but was not recorded in our work (Fig. 1). The total emission of $\mathrm{CO}_{2}$ from the apatite lattice was $3.05 \mathrm{wt} \%$, which can be considered as a characteristic value for vertebrate bioapatite (Michel et al. 1995; Wilson et al. 1999).

Data on the changes in lattice parameter values during heating are presented in Table 1 and Fig. 2. The shape of the function for lattice parameter $a$ is almost identical to that reported earlier by Rogers \& Daniels (2002), though slightly shifted towards higher values. We explain this as being caused by a different starting value, namely, the taxa-specific ratio of $\mathrm{OH} / \mathrm{F}$. The end-phase lattice parameter $a$ value is similar to the heated lingulate shell apatite (Nemliher et al. 2004b). The function of the lattice parameter $c$ at heating, however, is clearly different from those reported earlier (Rogers \& Daniels 2002). Moreover, even the direction of the function $c_{\mathrm{t}}=f\left(c_{0}, \mathrm{t}^{\circ}\right)$ of the apatite of bony fish was contrary to that of human bone, while the values of the lattice parameter $c$, heated up to $900^{\circ} \mathrm{C}$, were pretty close. Here we explain such a nonlinear character of both lattice parameter changes as being caused by preferred emanation of the $\mathrm{CO}_{3}$ ion from the B-site (up to temperatures of $400-500^{\circ} \mathrm{C}$ ) and its possible transition to the A-site at higher temperatures (sensu Elliott 1994; Ivanova et al. 2001). This assumption is also supported by the non-concurrency in the character of changes in different lattice directions at the same temperature - this phenomenon reflects unisotropic character of thermal behaviour due to planar configuration of the $\mathrm{CO}_{3}$ ion.

From the thermal behaviour of lattice parameters during heating it might be concluded that as end-member the apatite with lattice parameters $a=9.419 \AA$ and $c=6.881 \AA$ forms. These values are distinctively different from those of fossil apatite (Nemliher et al. 2004a). The process of bioapatite fossilization has also been reported to result in recrystallization of apatite particles, during which $\mathrm{OH}$
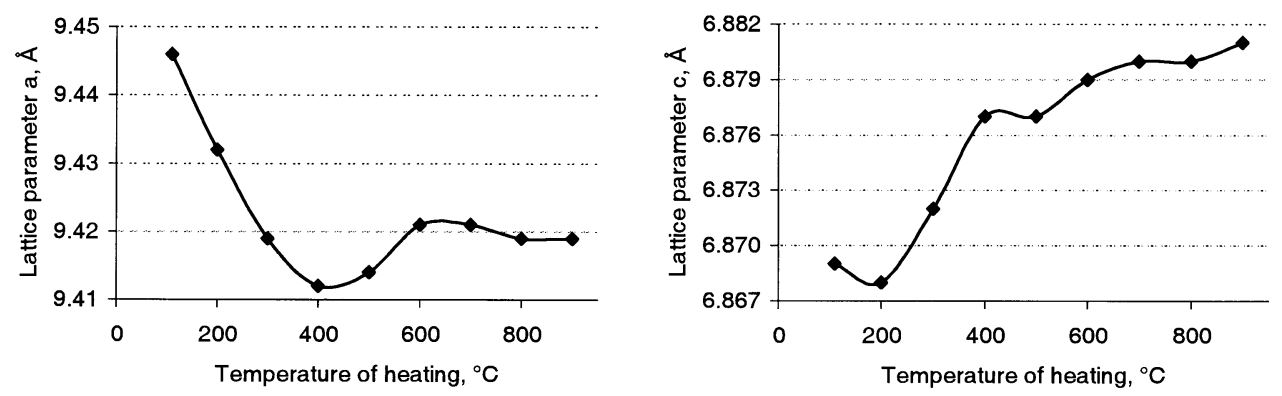

Fig. 2. Lattice parameters of vertebrae apatite as a function of heating. 
disappears from the apatite lattice and $\mathrm{CO}_{3}-\mathrm{F}$-apatite forms. This apatite variety is stable in diagenetical conditions (Nemliher \& Kallaste 2002).

Considering the chemical composition and positioning of ions in the apatite lattice (i.e. lattice parameter values), the heating does not model the fossilization processes. Thus, a perfect match of those processes, found by Golubev (1981) for coccolithophorides, does not work in case of compositional changes in apatitic mineralized tissues.

Data on crystallinity changes (interpreted as being caused by crystallite dimensions) during heating are presented in Fig. 3. Functional relationships between bioapatite heating temperature and crystallite dimensions in the directions of hk0 and 001 display a quasi-exponential correlation. Crystallite sizes change only little during heating up to $500^{\circ} \mathrm{C}$, but at higher temperatures a clear trend towards an increase in crystallite dimensions is observed. The increase in crystallite dimensions in both directions is the greatest when the processed residue reaches a temperature higher than $600^{\circ} \mathrm{C}$. It is essential to point out that these drastic changes take place at the temperature we previously attributed to emanation of the $\mathrm{CO}_{3}$ ion from the apatite lattice from the B-site. Thus, it might be suspected that some changes in the chemical nature of bioapatite are a precondition for the crystallinity change.

Crystallite dimensions found for real fossil vertebrae of bony fishes (Nemliher et al. 2004a) display a random character $(\sim 200 \times 400 \AA)$, being, however, considerably larger than those of Recent material $(60 \times 160 \AA)$. Our calculations show that the apatite of Recent pike vertebrae heated up to $900^{\circ} \mathrm{C}$ consists of crystallites larger than $1000 \times 1000 \AA$. These values are close to the upper limit recorded for fossil bioapatite (Nemliher et al. 2004a). So, we may conclude that considering the process of the loss of organo-mineral co-polymer properties of biomineralized tissue (sensu Golubev 1981), heating agrees well with the process of fossilization.

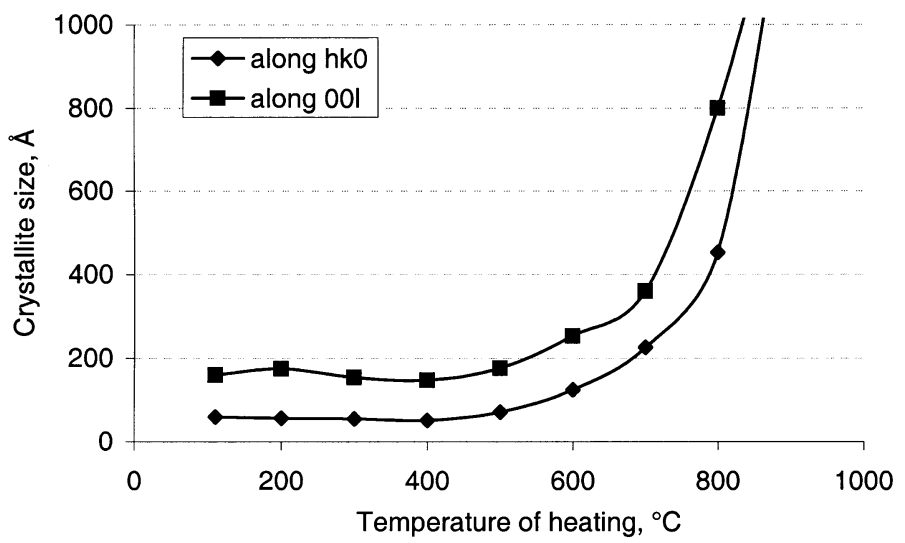

Fig. 3. Change in crystallite dimensions during heating in $\mathrm{hk} 0$ and 001 directions. 


\section{CONCLUSIONS}

From the thermal behaviour of XRD properties of apatite of Recent pike vertebrae we can draw the following conclusions: (1) heating results in a weight loss of about $3.05 \mathrm{wt} \%$, caused by emanation of carbonate ion from bioapatite lattice; (2) during this process the values of apatite lattice parameters change in a complicated manner and have several extremums, which is different from the known fossilization trend; the apatite, heated up to $900^{\circ} \mathrm{C}$ has lattice parameters $a=9.419 \AA$ and $c=6.881 \AA$; and (3) aggregation of crystallites takes place during heating, being strongest at temperatures higher than $600^{\circ} \mathrm{C}$; at the temperature of $900^{\circ} \mathrm{C}$ crystallites achieve approximate dimensions of $1000 \times 1000 \AA$.

\section{ACKNOWLEDGEMENT}

This work was supported by the Estonian Science Foundation (grants Nos. 5275 and 5922).

\section{REFERENCES}

Elliott, J. C. 1994. Structure and chemistry of apatites and other calcium orthophosphates. Stud. Inorg. Chem., 18.

Golubev, S. N. 1981. Real'nye kristally v skeletakh kokkolitophorid. Nauka, Moscow (in Russian).

Ivanova, T. I., Frank-Kamenetskaya, O. V., Kol'tsov, A. B. \& Ugolkov, V. L. 2001. Crystal structure of calcium-deficient carbonated hydroxyapatite. Thermal decomposition. J. Solid State Chem., 160, 340-349.

McArthur, J. M. 1985. Francolite geochemistry - compositional controls during formation, diagenesis, metamorphism and weathering. Geochim. Cosmochim. Acta, 49, 23-35.

McConnell, D. 1973. Apatite, Its Crystal Chemistry, Mineralogy, Utilization and Geologic and Biologic Occurrences. Springer, New York.

Michel, V., Ildefonse, P. \& Morin, G. 1995. Chemical and structural changes in Cervus elaphus tooth enamels during fossilization (Lazaret cave): a combined IR and XRD Rietveld analysis. Appl. Geochem., 10, 145-159.

Nemliher, J. \& Kallaste, T. 2002. Post mortem alteration of shell apatite of Discinisca tenuis from Lüderitz, Namibia. Lithol. \& Min. Res., 37, 18-24.

Nemliher, J. \& Puura, I. 1996. Upper Cambrian basal conglomerate of the Kallavere Formation on the Pakri Peninsula, NW Estonia. Proc. Estonian Acad. Sci. Geol., 45, 1-8.

Nemliher, J., Kallaste, T. \& Puura, I. 1997. Hydroxyapatite varieties in Recent fish scales. Proc. Estonian Acad. Sci. Geol., 46, 187-196.

Nemliher, J., Laas, T., Kallaste, T. \& Puura, I. 1996. Mineral composition of the dermal skeleton of the Devonian fishes from Estonia. Proc. Estonian Acad. Sci. Geol., 45, 203-215.

Nemliher, J. G., Baturin, G. N., Kallaste, T. E. \& Murdmaa, I. O. 2004a. Transition of hydroxylapatite of bony phosphate from the sea-floor during fossilization. Lithol. \& Min. Res., 39, 539-551.

Nemliher, J., Kurvits, T., Kallaste, T. \& Puura, I. 2004b. Apatite varieties in the shell of a Cambrian lingulate brachiopod Obolus apollinis Eichwald. Proc. Estonian Acad. Sci. Geol., 53, 246256. 
Person, A., Bocherens, H., Mariotti, A. \& Renard, M. 1996. Diagenetic evolution and experimental heating of bone phosphate. Palaeogeogr. Palaeoclimatol. Palaeoecol., 126, 135-149.

Peters, F., Schwartz, K. \& Epple, M. 2000. The structure of bone studied with synchrotron X-ray diffraction, X-ray absorption spectroscopy and thermal analysis. Thermochim. Acta, 361, $131-138$.

Puura, I. \& Nemliher, J. 2001. Apatite varieties in Recent and fossil linguloid brachiopod shells. In Brachiopods Past and Present (Brunton, C. H. C., Cocks, L. R. M. \& Long, S. L., eds.). Systematics Assoc. Spec. Vol. Ser., 63, 7-16.

Rogers, K. D. \& Daniels, P. 2002. An X-ray diffraction study of the effects of heat treatment on bone mineral microstructure. Biomaterials, 23, 2577-2585.

Wilson, R. M., Elliott, J. C. \& Dowker, S. E. P. 1999. Rietveld refinement of the crystallographic structure of human dental enamel apatites. Amer. Miner., 84, 1406-1414.

\title{
Kaasaegse haugi (Esox lucius L.) luude apatiidi termilised omadused
}

\author{
Jüri Nemliher ja Toivo Kallaste
}

Kasutades röntgendifraktomeetrilist analüüsi, uuriti kaasaegse haugi selgroolülide bioapatiidi omadusi. Uuritavat proovi kuumutati järk-järgult kuni $900^{\circ} \mathrm{C}$; võrreldes prooviga, mida kuumutati kuni $900^{\circ} \mathrm{C}$, oli kaalukadu 3,05 massiprotsenti. Kuni $900^{\circ} \mathrm{C}$ kuumutatud bioapatiidi võrekonstantide väärtusteks leiti: $a=9,419 \AA$ ja $c=6,881 \AA$. Kuumutamise kestel leidis aset kristalliitide ümberkristalliseerumine, mille kiirus oli suurim $600^{\circ} \mathrm{C}$ korral. Kuni $900^{\circ} \mathrm{C}$ kuumutatud bioapatiidi kristalliitide mõõtmed olid suuremad kui $1000 \times 1000 \AA$. 